\title{
CRYSTAL STRUCTURE OF $\left\{\left[\mathrm{La}_{2}\left(\mathrm{CNCH}_{2} \mathrm{COO}\right)_{6}\left(\mathrm{H}_{2} \mathrm{O}\right)_{4}\right] \cdot \mathrm{H}_{2} \mathrm{O}\right\}_{\mathrm{n}} \mathrm{COMPLEX}$
}

\author{
Ana Lazarescu $^{a^{*}}$, Elena Melnic ${ }^{\mathrm{b}}$, Sergiu Shova ${ }^{\mathrm{a}}$, Victor Kravtsov ${ }^{\mathrm{b}}$, Constantin Turta $^{\mathrm{a}}$ \\ ${ }^{a}$ Institute of Chemistry of Academy of Sciences of Moldova, 3, Academiei str., Chisinau MD-2028, Republic of Moldova \\ ${ }^{b}$ Institute of Applied Physics of Academy of Sciences of Moldova, 5, Academiei str., Chisinau, MD-2028, Republic of Moldova \\ *e-mail: analazarescu@yahoo.com; phone: (+373 22) 7397 22; fax: (+373 22) 739954
}

\begin{abstract}
The lanthanum(III) cyanoacetate complex of formula $\left\{\left[\mathrm{La}_{2}\left(\mathrm{CNCH}_{2} \mathrm{COO}\right)_{6}\left(\mathrm{H}_{2} \mathrm{O}\right)_{4}\right] \cdot \mathrm{H}_{2} \mathrm{O}\right\}_{\mathrm{n}}(\mathbf{1})$, has been prepared and characterized by X-ray diffraction analysis. Compound crystallizes in the triclinic centrosymmetric space group $P-1$ (No.2), $a=8.997(5) \AA, b=9.251(5) \AA, c=9.728(5) \AA, \alpha=67.849(5)^{\circ}, \beta=84.224(5)^{\circ}, \gamma=81.351(5)^{\circ}$. Single-crystal X-ray diffraction study reveals that crystals of 1 exhibits one-dimensional coordination polymer structure, which is composed of cyanoacetate bridged lanthanum(III) ions. The $\mathrm{O}_{9}$ coordination surrounding of $\mathrm{La}$ cation is completed by oxygen atoms of six carboxylate ligands that are coordinated in the bidentate bridging and tridentate-chelating bridging mode and two water molecules. The cations are bridged in a polymeric chain by four exo-bidentate cyanoacetate ligands or through $\mu_{2}-\mathrm{O}$ function of two other chelato-bridgind cyanoacetate ligands. The La $\cdots$ La separation along the polymer is equal to 4.754(3) $\AA$ and 4.608(2) $\AA$.
\end{abstract}

Keywords: coordination polymers, lanthanum (III), cyanoacetic acid, crystal structure.

Received: November 2014/Revised final: January 2015/Accepted: February 2015

\section{Introduction}

The synthesis of functional rare-earth coordination polymers with various $\mathrm{N}$ - and / or O-donor ligands has attracted increasing interest, due to their various topologies [1-3] and potential applications as optical, electronic and magnetic materials [4-7].

The carboxylate ligands are attractive candidates for construction of the polymeric networks due to their versatile functions as bridges or terminal groups, which lead to generation of dimers [8,9], 1D chains [10], 2D-layers [11], and 3D- polymeric structures [12].

However, investigation of lanthanide complexes with cyanoacetic acid anion as ligand is very scarce $[13,14]$. Our previous investigations of $3 d$ and $4 f$ metal complexes with cyanoacetate anions have demonstrated that copper(II) ion has $\left\{\mathrm{O}_{4}{ }^{\text {(carbox.) }} \mathrm{N}^{(\mathrm{CN})}\right\}$ coordination node, while neodymium(III) ion $-\left\{\mathrm{O}_{7}{ }^{(\text {carbox. })} \mathrm{O}_{2}{ }^{\left(\mathrm{H}_{2} \mathrm{O}\right)}\right\}$, respectively $[15,16]$. The study of magnetic properties of gadolinium(III) cyanoacetate complex has shown that external magnetic field induces two slow relaxation processes, while heat capacity and direct current susceptibility measurements at very low temperatures has indicated strong single ion anisotropy, due to the Kramer's doublet of the ground state [17].

In continuation of our research on the use of cyanoacetic acid with both $\mathrm{O}$ - and $\mathrm{N}$ - potential donor atoms as a ligand for $4 f$ cations $[16,17]$ and $d$-block transition metal [15], we have synthesized and structurally characterized the $\left\{\left[\mathrm{La}_{2}\left(\mathrm{CNCH}_{2} \mathrm{COO}\right)_{6}\left(\mathrm{H}_{2} \mathrm{O}\right)_{4}\right] \cdot \mathrm{H}_{2} \mathrm{O}\right\}_{\mathrm{n}}$ compound by single crystal X-ray method.

\section{Experimental Synthesis}

All reagents of analytical grade were commercially purchased and used without further purification. Elemental analyses $(\mathrm{C}, \mathrm{H}, \mathrm{N})$ were performed on a Elemental Analyzer vario EL(III). The lanthanum content in the complex was determined gravimetrically as stable oxide by precipitating lanthanide (III) ions with ammonium hydroxide [18].

$\left\{\left[\mathrm{La}_{2}\left(\mathrm{CNCH}_{2} \mathrm{COO}\right)_{6}\left(\mathrm{H}_{2} \mathrm{O}\right)_{4}\right] \cdot \mathrm{H}_{2} \mathrm{O}\right\}_{n}(\mathbf{1})$. Solution of cyanoacetic acid $(0.51 \mathrm{~g}, 6 \mathrm{mmol})$ in water $(10 \mathrm{~mL})$ was added to $\mathrm{La}_{2} \mathrm{O}_{3}(0.32 \mathrm{~g}, 1 \mathrm{mmol})$. After stirring the resulting solution was passed through a glass filter. The filtrate was stored at room temperature for some weeks, whereupon the suitable for X-ray analysis colorless crystals of the product appeared. The crystals were collected by filtration, dried under reduced pressure and kept in desiccator. Yield: $52 \%$. Anal. found (calc.)\%: for $\left\{\mathrm{C}_{9} \mathrm{H}_{12} \mathrm{~N}_{3} \mathrm{O}_{9} \mathrm{La}\right\}_{n}, \mathrm{C}, 23.99$ (24.29); H, 2.43 (2.69); $\mathrm{N} 9.07$ (9.45); La, 30.89 (31.22). IR data (Nujol, $\mathrm{cm}^{-1}$ ): 3545br, 3430br, 3250br, 2265sh, 1705s, 1600vs, 1580s, 1545s, 1410s, 1264m, 1195m, 955w, 930m, $915 \mathrm{~m}$, $700 \mathrm{~m}, 570 \mathrm{~m}, 515 \mathrm{~m}$.

\section{Physical measurements}

IR spectrum of polycrystalline sample was recorded on Perkin Elmer spectrum 100 FT IR Spectrometer in the range of 4000-400 $\mathrm{cm}^{-1}$.

\section{$X$-ray crystallography}

The X-ray data for $\mathbf{1}$ were collected at room temperature on an Oxford Diffraction Xcalibur diffractometer equipped with CCD area detector and a graphite monochromator utilizing $\mathrm{MoK} \alpha$ radiation. The crystals were placed at $40 \mathrm{~mm}$ from the CCD detector. The data were processed using the CrysAlis package of Oxford Diffraction [19]. The final unit cell dimensions were obtained and refined on an entire data set. The structures were solved by direct methods using SHELX-97 program package [20] and refined with full-matrix least squares method with anisotropic thermal parameters for the non-hydrogen atoms. The $\mathrm{C}\left(s p^{2}\right)$-bound $\mathrm{H}$ atoms were placed in calculated positions and were treated 
using a riding model approximation with $\operatorname{Uiso}(\mathrm{H})=1.2 \mathrm{Ueq}(\mathrm{C})$, while the hydrogen atoms of water molecules were refined with isotropic displacement parameter Uiso $(\mathrm{H})=1.5 \mathrm{Ueq}(\mathrm{O})$ using DFIX restrain instruction. The figures were produced using MERCURY [21]. The X-ray data and details of the refinement for $\mathbf{1}$ are summarized in Table 1, the selected geometric parameters are given in Table 2 and the hydrogen-bonding geometry is given in Table 3. CCDC 1032624 contains the crystallographic data for $\mathbf{1}$. These data can be obtained free of charge from The Cambridge Crystallographic Data Centre via www.ccdc.cam.ac.uk/data_request/cif.

Table 1

Crystal and structure refinement data for 1.

\begin{tabular}{|c|c|}
\hline Parameter & Value \\
\hline Compound & 1 \\
\hline Empirical formula & $\mathrm{C}_{9} \mathrm{H}_{12} \mathrm{~N}_{3} \mathrm{O}_{9} \mathrm{La}$ \\
\hline Formula weight & 445.13 \\
\hline$T(\mathrm{~K})$ & 293(2) K \\
\hline Crystal system & Triclinic \\
\hline Space group & $P-1$ \\
\hline Z & 2 \\
\hline$a, \AA$ & $8.997(5)$ \\
\hline$b, \AA$ & $9.251(5)$ \\
\hline$c, \AA$ & $9.728(5)$ \\
\hline$\alpha,\left({ }^{\circ}\right)$ & $67.849(5)$ \\
\hline$\beta,\left(^{\circ}\right)$ & $84.224(5)$ \\
\hline$\gamma,\left({ }^{\circ}\right)$ & $81.351(5)$ \\
\hline$V, \AA^{3}$ & $740.5(7)$ \\
\hline$D_{\text {calc }}\left(\mathrm{g} \mathrm{cm}^{-3}\right)$ & 1.996 \\
\hline$\mu\left(\mathrm{mm}^{-1}\right)$ & 2.934 \\
\hline$F(000)$ & 432 \\
\hline Crystal size (mm) & $0.30 \times 0.20 \times 0.15$ \\
\hline$\theta_{\min }, \theta_{\max }\left({ }^{\circ}\right)$ & $2.62-25.99$ \\
\hline Reflections collected/unique & $5555 / 2899$ \\
\hline Reflections with $[I>2 \sigma(I)]$ & 2810 \\
\hline Data/restraints/parameters & $2899 / 9 / 217$ \\
\hline Goodness-of-fit (GOF)on $F^{2}$ & 1.000 \\
\hline$R 1, w R 2[I>2 \sigma(I)]$ & $0.0182,0.0464$ \\
\hline$R 1, w R 2$ (all data) & $0.0190,0.0468$ \\
\hline$\Delta \rho_{\max }, \Delta \rho_{\min },\left(e \times \AA^{-3}\right)$ & $0.416,-0.689$ \\
\hline
\end{tabular}

Table 2

Selected bond lengths $(\AA)$ and angles $\left({ }^{\circ}\right)$ in coordination metal environment in 1.

\begin{tabular}{|c|c|c|c|}
\hline Bond & $d,(\AA)$ & Bond & $d,(\AA)$ \\
\hline $\mathrm{La}-\mathrm{O}(1)$ & $2.511(2)$ & $\mathrm{La}-\mathrm{O}(3)^{i i}$ & $2.804(2)$ \\
\hline $\mathrm{La}-\mathrm{O}(2)$ & $2.456(2)$ & $\mathrm{La}-\mathrm{O}(6)^{i}$ & $2.490(2)$ \\
\hline $\mathrm{La}-\mathrm{O}(3)$ & $2.525(2)$ & $\mathrm{La}-\mathrm{O}(1 w)$ & $2.578(2)$ \\
\hline $\mathrm{La}-\mathrm{O}(4)$ & $2.451(2)$ & $\mathrm{La}-\mathrm{O}(2 w)$ & $2.667(2)$ \\
\hline $\mathrm{La}-\mathrm{O}(5)$ & $2.639(2)$ & & - \\
\hline Angle & $\omega,($ deg $)$ & Angle & $\omega,($ deg) \\
\hline $\mathrm{O}(1)-\mathrm{La}-\mathrm{O}(2)$ & $117.39(7)$ & $\mathrm{O}(3)-\mathrm{La}-\mathrm{O}(3)^{i i}$ & $60.38(6)$ \\
\hline $\mathrm{O}(1)-\mathrm{La}-\mathrm{O}(3)^{i i}$ & $121.23(5)$ & $\mathrm{O}(3)-\mathrm{La}-\mathrm{O}(1 w)$ & $74.69(7)$ \\
\hline $\mathrm{O}(1)-\mathrm{La}-\mathrm{O}(3)$ & $79.09(6)$ & $\mathrm{O}(3)-\mathrm{La}-\mathrm{O}(2 w)$ & $78.71(6)$ \\
\hline $\mathrm{O}(1)-\mathrm{La}-\mathrm{O}(4)$ & $75.31(7)$ & $\mathrm{O}(4)-\mathrm{La}-\mathrm{O}(3)^{i i}$ & $114.09(6)$ \\
\hline $\mathrm{O}(1)-\mathrm{La}-\mathrm{O}(5)$ & $138.55(7)$ & $\mathrm{O}(4)-\mathrm{La}-\mathrm{O}(5)$ & $77.08(6)$ \\
\hline $\mathrm{O}(1)-\mathrm{La}-\mathrm{O}(6)^{i}$ & $73.48(7)$ & $\mathrm{O}(4)-\mathrm{La}-\mathrm{O}(6)^{i}$ & $117.37(7)$ \\
\hline $\mathrm{O}(1)-\mathrm{La}-\mathrm{O}(1 w)$ & $143.16(6)$ & $\mathrm{O}(4)-\mathrm{La}-\mathrm{O}(1 w)$ & $138.48(7)$ \\
\hline $\mathrm{O}(1)-\mathrm{La}-\mathrm{O}(2 w)$ & $67.33(6)$ & $\mathrm{O}(4)-\mathrm{La}-\mathrm{O}(2 w)$ & $68.49(7)$ \\
\hline $\mathrm{O}(2)-\mathrm{La}-\mathrm{O}(3)$ & $141.97(6)$ & $\mathrm{O}(5)-\mathrm{La}-\mathrm{O}(3)^{i i}$ & $47.66(5)$ \\
\hline $\mathrm{O}(2)-\mathrm{La}-\mathrm{O}(3)^{i i}$ & $120.81(7)$ & $\mathrm{O}(5)-\mathrm{La}-\mathrm{O}(6)^{i}$ & $147.68(6)$ \\
\hline $\mathrm{O}(2)-\mathrm{La}-\mathrm{O}(4)$ & $73.24(7)$ & $\mathrm{O}(5)-\mathrm{La}-\mathrm{O}(1 w)$ & $75.17(7)$ \\
\hline $\mathrm{O}(2)-\mathrm{La}-\mathrm{O}(5)$ & $82.64(7)$ & $\mathrm{O}(5)-\mathrm{La}-\mathrm{O}(2 w)$ & $74.06(6)$ \\
\hline $\mathrm{O}(2)-\mathrm{La}-\mathrm{O}(6)^{i}$ & $75.29(7)$ & $\mathrm{O}(6)^{i}-\mathrm{La}-\mathrm{O}(3)^{i i}$ & $128.54(6)$ \\
\hline $\mathrm{O}(2)-\mathrm{La}-\mathrm{O}(1 w)$ & $73.10(7)$ & $\mathrm{O}(1 w)-\mathrm{La}-\mathrm{O}(3)^{i i}$ & $65.62(6)$ \\
\hline
\end{tabular}


Continuation of Table 2

\begin{tabular}{cccc}
\hline Angle & $\omega,($ deg) & Angle & $\omega,($ deg) \\
\hline $\mathrm{O}(2)-\mathrm{La}-\mathrm{O}(2 w)$ & $138.57(6)$ & $\mathrm{O}(1 w)-\mathrm{La}-\mathrm{O}(2 w)$ & $130.08(6)$ \\
$\mathrm{O}(3)-\mathrm{La}-\mathrm{O}(4)$ & $144.14(6)$ & $\mathrm{O}(1 w)-\mathrm{La}-\mathrm{O}(6)^{i}$ & $75.99(7)$ \\
$\mathrm{O}(3)-\mathrm{La}-\mathrm{O}(5)$ & $108.01(6)$ & $\mathrm{O}(2 w)-\mathrm{La}-\mathrm{O}(3)^{i i}$ & $64.55(6)$ \\
$\mathrm{O}(3)-\mathrm{La}-\mathrm{O}(6)^{i}$ & $77.77(6)$ & $\mathrm{O}(2 w)-\mathrm{La}-\mathrm{O}(6)^{i}$ & $137.25(6)$ \\
\hline
\end{tabular}

Symmetry code: ${ }^{i}-x+1,-y,-z+1 ;{ }^{i i}-x+1,-y+1,-z+1$

Table 3

Geometric parameters of hydrogen bonds $(\AA, \mathrm{deg})$ in 1.

\begin{tabular}{|c|c|c|c|c|}
\hline$D-H \cdots A$ & $d(H \cdots A)$ & $d(D \cdots A)$ & $Đ(D H A)$ & $\begin{array}{c}\text { Symmetry transformation } \\
\text { for acceptor }\end{array}$ \\
\hline $\mathrm{O} 1 w-\mathrm{H} 1 w 1 \cdots \mathrm{N} 3$ & $2.28(2)$ & $3.106(4)$ & $168(3)$ & $x, y, z$ \\
\hline $\mathrm{O} 1 w-\mathrm{H} 2 w 1 \cdots \mathrm{O} 2 w$ & $1.92(2)$ & $2.771(3)$ & $161(3)$ & $-x+1,-y+1,-z+1$ \\
\hline $\mathrm{O} 2 w-\mathrm{H} 2 w 2 \cdots \mathrm{O} 3 w$ & $1.90(2)$ & $2.770(3)$ & $164(3)$ & $x, y, z$ \\
\hline $\mathrm{O} 2 w-\mathrm{H} 1 w 2 \cdots \mathrm{O} 3 w$ & $2.02(2)$ & $2.809(3)$ & $153(2)$ & $-x+1,-y+1,-z$ \\
\hline $\mathrm{O} 3 w-\mathrm{H} 1 w 3 \cdots \mathrm{N} 1$ & $2.29(3)$ & $2.951(4)$ & $136(3)$ & $-x+2,-y+1,-z$ \\
\hline $\mathrm{O} 3 w-\mathrm{H} 2 w 3 \cdots \mathrm{N} 2$ & $1.95(2)$ & $2.802(3)$ & $176(3)$ & $x, y+1, z$ \\
\hline
\end{tabular}

\section{Results and discussion}

The reaction of lanthanum(III) oxide with cyanoacetic acid in a molar ratio of 1:3 in water solution leads to polymeric complex with the composition $\left\{\left[\mathrm{La}_{2}\left(\mathrm{CNCH}_{2} \mathrm{COO}\right)_{6}\left(\mathrm{H}_{2} \mathrm{O}\right)_{4}\right] \times \mathrm{H}_{2} \mathrm{O}\right\}_{\mathrm{n}}(\mathbf{1})$. The complex is a colorless, air hygroscopic crystalline solid, readily dissolves in water, but is insoluble in organic solvents, such as methanol, acetone and acetonitrile. The IR spectrum shows the absorption band at $2265 \mathrm{~cm}^{-1}$, which is characteristic to the $v(\mathrm{C} \equiv \mathrm{N})$ vibrations of the ligand.

Here we report the results of X-ray study of the lanthanum(III) compound with cyanoacetate ligands, which is a linear polymer of composition $\left\{\left[\mathrm{La}_{2}\left(\mathrm{CNCH}_{2} \mathrm{COO}\right)_{6}\left(\mathrm{H}_{2} \mathrm{O}\right)_{4}\right] \times \mathrm{H}_{2} \mathrm{O}\right\}_{n}$. Compound crystallizes in the triclinic centrosymmetric space group $P-1, a=8.997(5) \AA, b=9.251(5) \AA, c=9.728(5) \AA, \alpha=67.849(5)^{\circ}, \beta=84.224(5)^{\circ}$, $\gamma=81.351(5)^{\circ}, \mathrm{V}=740.5(7) \AA^{3}$ and is isostructural to the reported earlier $\mathrm{Nd}$ analog [16]. The inversion centers related to La cations are linked in 1D structure by carboxylic groups of cyanoacetate ligands, which exhibit different binding modes (Figure 1).

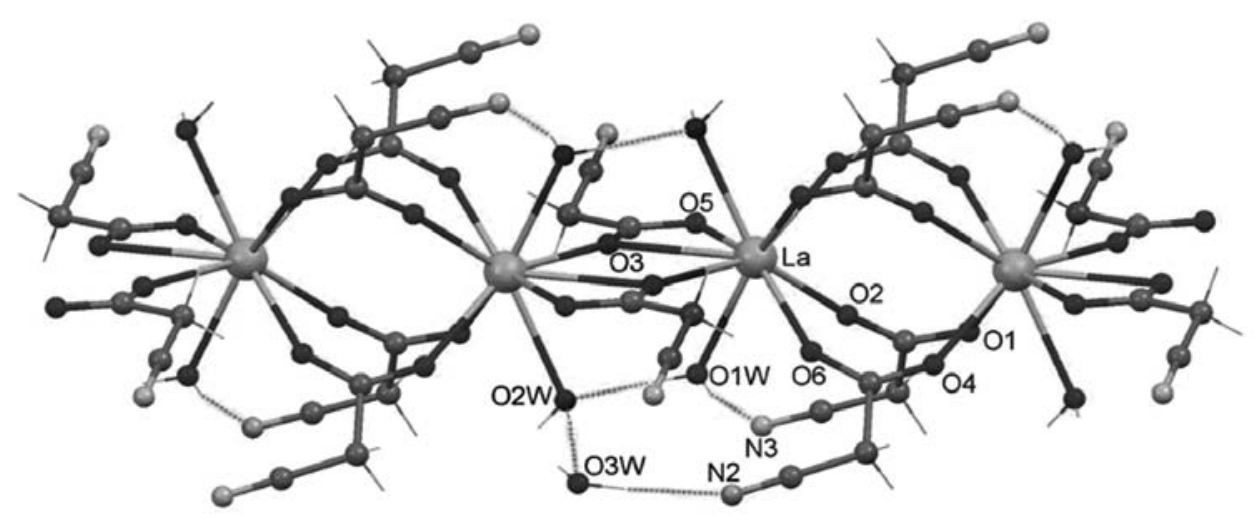

Figure 1. View of polymeric chain.

The La cation is linked to the center of symmetry related neighboring La cations either by four cyanoacetic ligands, acting as syn-syn (c-2-c) bidentate bridges (La-O2, 2.455(2); La-O6, 2.490(2); La-O1', 2.511(2); La-O4', $2.450(2) \AA)$, or through two tridentate $\left(3_{2}\right.$-c) chelate-bridging ligands with the La - O3 bond lengths of $2.524(2)$ and 2.806(2) Å, respectively.

Two different $\mathrm{La} \cdots$ La separations in the polymer chain alternate and are equal to 4.755 and $4.608 \AA$, respectively. The shorter of the La $\cdots$ La distance is related with monoatomic bridging function of carboxylic group in the second case. The coordination surrounding of lanthanum is completed to nine by two coordinated water molecules $\mathrm{O}(1 \mathrm{w})$ and $\mathrm{O}(2 \mathrm{w})(\mathrm{La}-\mathrm{O}(1 \mathrm{w}), 2.579(2)$ and $\mathrm{La}-\mathrm{O}(2 \mathrm{w}), 2.664(2) \AA)$. The coordination polyhedron of lanthanum is a monocapped tetragonal antiprism. The comparison of average La-O distances for acting as syn-syn (c-2-c) bidentate bridges $(2.477 \AA$ ) ligands, chelate-bridging ligands $(2.525,2.639$ and $2.804 \AA)$ and coordinated water molecules $(2.623 \AA)$ in 1 with the corresponding values in related $\mathrm{Nd}$ analog [16] $(2.420,2.463,2.587 \AA$ and $2.831,2.590 \AA)$ revealed well agreement 
with the difference in ionic radii of nine coordinated $\mathrm{La}^{\mathrm{III}}(1.36 \AA)$ and $\mathrm{Nd} \mathrm{d}^{\mathrm{III}}(1.30 \AA)$ [22]. The cyano group of the cyanoacetate ligands does not coordinate to the lanthanide cation. The coordinated water molecules are involved in intra- and inter-chain hydrogen bonds (Table 3).

In the crystal, the parallel polymer chains run along a crystallographic axis and are united into a threedimensional network through a system of hydrogen bonds involving water molecules and nitrogen atoms of cyanoacetic ligands (Figure 2).

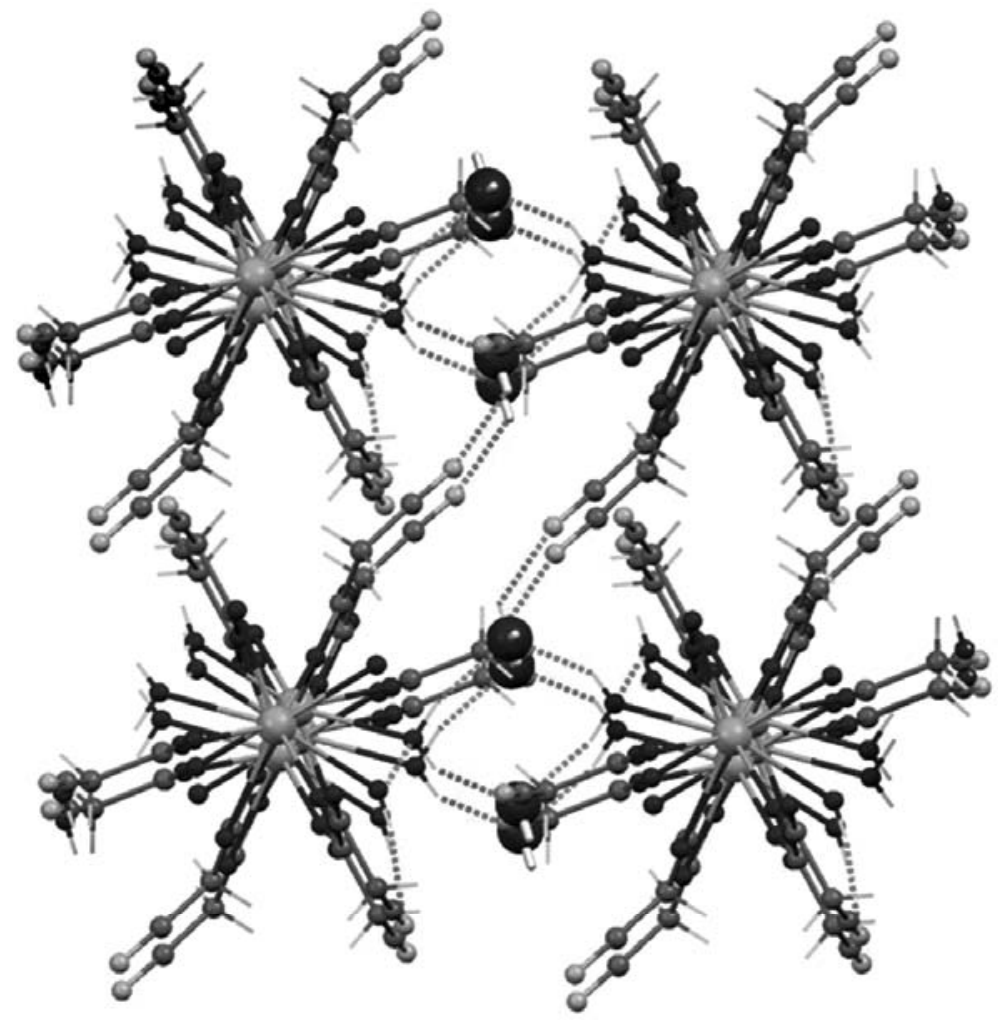

Figure 2. Hydrogen bonded parallel polymer chains in the crystal structure of $\left\{\left[\mathrm{La}_{2}\left(\mathrm{CNCH}_{2} \mathrm{COO}\right)_{6}\left(\mathrm{H}_{2} \mathrm{O}\right)_{4}\right] \cdot \mathrm{H}_{2} \mathrm{O}\right\}_{\mathrm{n}}$. Solvent water molecules $\mathrm{O} 3 \mathrm{w}$ are shown by bigger radii red spheres.

\section{Conclusions}

The lanthanum(III) cyanoacetate polymer of formula $\left\{\left[\mathrm{La}_{2}\left(\mathrm{CNCH}_{2} \mathrm{COO}\right)_{6}\left(\mathrm{H}_{2} \mathrm{O}\right)_{4}\right] \cdot 2 \mathrm{H}_{2} \mathrm{O}\right\}_{n}$ (1) has been synthesized and characterized by single-crystal X-ray diffraction. The complex was found to be isostructural to $\mathrm{Nd}$ analog. The cyano-group of the ligand is not coordinated to the lanthanide ion.

\section{References}

1. $\quad$ Decadt, R.; Van Hecke, K; Depla, D; Leus, K; Weinberger, D; Van Driessche, I.; Van Der Voort, P; Van Deun, R. Synthesis, crystal structures, and luminescence properties of carboxylate based rare-earth coordination polymers. Inorganic Chemistry, 2012, 51, pp. 11623-11634.

2. Qin, C.; Wang. X.I.; Wang, E.B.; Su, Z.M. A Series of three-dimensional lanthanide coordination polymers with rutile and unprecedented rutile-related topologies. Inorganic Chemistry, 2005, 44, pp. 7122-7129.

3. Gai, Y.-Li; Xiong, K.-C.; Chen, L.; Bu, Y.; Li, X.-J.; Jiang, F.-L.; Hong, M.-C. Visible and NIR Photoluminescence Properties of a Series of Novel Lanthanide-Organic Coordination Polymers Based on HydroxyquinolineCarboxylate Ligands. Inorganic Chemistry, 2012, 51, pp. 13128-13137.

4. Liu, C.M.; Xiong, M.; Zhang, D.Q.; Du, M.; Zhu, D.B. Two-and three-dimensional lanthanide-organic frameworks constructed using 1-hydro-6-oxopyridine-3-carboxylate and oxalate ligands. Dalton Transactions, 2009, 29, pp. 5666-5672.

5. Hasegawa, Ya.; Nakagawa, T.; Kawai, T. Recent progress of luminescent metal complexes with photochromic units. Coordination Chemistry Review, 2010, 254, pp. 2643-2651.

6. Cidália, M.G.dos Santos; Harte, A.J.; Quinn, S.J.; Gunnlaugsson, T. Recent developments in the field of supramolecular lanthanide luminescent sensors and self-assemblies. Coordination Chemistry Review, 2008, 252, pp. 2512-2527. 
7. Cunha-Silva, L.; Lima, S.; Ananias, D.; Silva, P.; Mafra, L.; Carlos, I.D.; Pillinger, M.; Valente, A.A.; Almeida Paz, P.A.; Rocha, J. Multi-functional rare-earth hybrid layered networks: photoluminescence and catalysis studies. Journal of Materials Chemistry, 2009, 19, pp. 2618- 2632.

8. Rohde, A.; Urland, W. Synthesis, crystal structures and magnetic behaviour of dimeric and tetrameric gadolinium carboxylates with trichloroacetic acid. Journal of Chemical Society, Dalton Transactions, 2006, 24, pp. 2974-2978.

9. Yi-Shan, S.; Bing, Y.; Zhen-Xia, C. Different crystal structure and photophysical properties of lanthanide complexes with 5-bromonicotinic acid. Journal of Solid State Chemistry, 2004, 177, pp. 3805-3814.

10. Chen, C.; Zhang, S.-Y.; Song, H.-B.; Shi, W.; Zhao, B.; Cheng, P. One-dimensional lanthanide coordination polymers as promising luminescent materials. Inorganica Chimica Acta, 2009, 362, pp. 2749-2745.

11. Mahata, P.; Ramya, K.V.; Natarajan, S.; Reversible water intercalation accompanied by coordination and color changes in a layered metal-organic framework. Inorganic Chemistry. 2009, 48, pp. 4942-4951.

12. Lu, W.-G.; Jiang, L.; Feng, X.-L.; Lu, T.-B. Three-dimensional lanthanide anionic metal-organic frameworks with tunable luminescent properties induced cation exchange. Inorganic Chemistry, 2009, 48, pp. 6997-6999.

13. Starynowicz P. Structure and electron spectroscopy of potassium triaquadecakis(cyanoacetato)trineodymate hexahydrate. Polish Journal of Chemistry, 1994, 68, pp. 621-629.

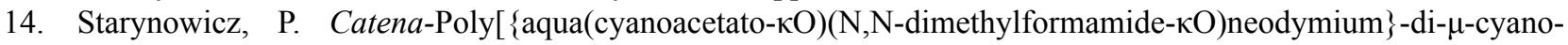

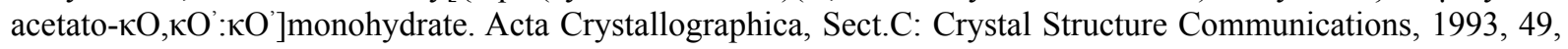
pp. 1621-1623.

15. Novitskii, G.; Shova, S.; Voronkova, V.; Korobcenko, L.; Gdanets, M.; Simonov, Iu.; Turta, C. Copper(II) cyanoacetate polymer: synthesis and structure. Russian Journal of Coordination Chemistry, 2001, 27, pp. 839-844 (in Russian).

16. Shova, S.G.; Simonov, Yu.A.; Gdaniec, M.; Novitskii, G.V.; Lazarescu, A.; Turta, K.I. Synthesis and Structure of catena- $\{\mathrm{Bis}(\mu$-cyanoacetato $(\mathrm{O}, \mathrm{O}, \mathrm{O} \notin))$ tetrakis $(\mu$-cyanoacetato $(\mathrm{O}, \mathrm{O} \notin))$ dineodymium(III). Russian Journal of Inorganic Chemistry, 2002, 47, pp. 946-952 (in Russian).

17. Arauzo, A.; Lazarescu, A.; Shova, S.; Bartolomé, E.; Cases, R.; Luzón, J.; Bartolomé, J.; Turta, C. Structural and magnetic properties of some lanthanide ( $\mathrm{Ln}=\mathrm{Eu}(\mathrm{III}), \mathrm{Gd}(\mathrm{III})$ and $\mathrm{Nd}(\mathrm{III}))$ cyanoacetate polymers: Field-induced slow magnetic relaxation in the Gd and Nd substitutions. Dalton Transactions, 2014, 43, pp. 12342-12356.

18. Charlot G. Methods of Analytical Chemistry. The Quantitative Analysis of Inorganic Compounds. Chemistry: Leningrad, 1965, 975 p. (in Russian).

19. CrysAlisPRO, Oxford Diffraction /Agilent Technologies UK Ltd, Yarnton, England.

20. Sheldrick, G.M. A short history of SHELX. Acta Crystallographica, 2008, A64, pp. 112-122.

21. Edgington, P.R.; McCabe, P.; Macrae, C.F.; Pidcock, E.; Shields, G.P.; Taylor, R.; Towler, M.; Van de Streek, J. Mercury: visualization and analysis of crystal structures. Journal of Applied Crystallography, 2006, 39, pp. 453-457.

22. Vainshtein, B.K., Indenbom, V.L.; Fridkin, V.M. Modern crystallography. Crystal structure. Science: Moscow, 1979, V. 2, pp. 77-78 (in Russian). 